\title{
イオン濃度制御キュウリ養液栽培における $\mathrm{NH}_{4}-\mathbf{N}$ 供給方法の検討
}

\author{
霧村雅昭・位田晴久 \\ 宮崎大学農学部８89-2192 宮崎市学園木花台西 1-1 \\ Studies on $\mathrm{NH}_{4}-\mathrm{N}$ Supply Method in Ion Concentration Controlled \\ Hydroponic System of Cucumber \\ Masaaki KIRIMURA and Haruhisa INDEN \\ Faculty of Agriculture, University of Miyazaki, Miyazaki 889-2192, Japan
}

\begin{abstract}
A technique for keeping a suitable $\mathrm{pH}$ value of nutrient solution without addition of acid and/or alkali were examined. Cucumber plants were cultivated with various methods of $\mathrm{NH}_{4}-\mathrm{N}$ supply in ion concentration controlled hydroponic system.

In the first experiment, plants were grown in solution culture for 6 days at 4 levels of initial $\mathrm{NH}_{4}-\mathrm{N}$ concentration. $\mathrm{NH}_{4}-\mathrm{N}$ absorption rate increases drastically and solution $\mathrm{pH}$ decreased as the $\mathrm{NH}_{4}-\mathrm{N}$ concentration increased.

In the second experiment, cucumber were cultivated with nutrient solution controlled by the IIAS (Integrated IonAdjuster System) or the PEIS (Popular Edition of Intelligent System) to investigate the effects of $\mathrm{NO}_{3}-\mathrm{N}: \mathrm{NH}_{4}-\mathrm{N}$ ratio, and concentrations of each $\mathrm{N}$ source on the growth and solution $\mathrm{pH}$. Solution $\mathrm{pH}$ decreased severely under PEIS and IIAS (set value of $\mathrm{NH}_{4}-\mathrm{N}$ concentration was $\left.8 \mathrm{mg} l^{-1}\right)$, and increased under IIAS $\left(\mathrm{NO}_{3}-\mathrm{N}^{-} \mathrm{NH}_{4}-\mathrm{N}=30: 1\right.$ or fuzzy) in this experiment. The results showed that $\mathrm{pH}$ of the nutrient solution for cucumber culture with IIAS management system could be stabilized by limiting $\mathrm{NH}_{4}-\mathrm{N}$ supply through the ratio basis control in which the ratio of $\mathrm{NO}_{3}-\mathrm{N}$ to $\mathrm{NH}_{4}-\mathrm{N}$ was kept at 30:1. However in the mid stage of cucumber growth with that system, the $\mathrm{pH}$ tended to increase gradually until harvesting stage, indicating that the relatively higher ratio of $\mathrm{NH}_{4}-\mathrm{N}$ supply in the mid stage than in other stages might be better to prevent the $\mathrm{pH}$ fluctuation.

To maintain $\mathrm{pH}$ value of the nutrient solution, the control method through the $\mathrm{NO}_{3}-\mathrm{N}: \mathrm{NH}_{4}$ $\mathrm{N}$ ratio was more feasible than the method through keeping the concentration of $\mathrm{NH}_{4}-\mathrm{N}$.
\end{abstract}

Keywords: EC, laborsaving, $\mathrm{pH}$

緒言

これまでに著者らは，養液栽培における培養液管理の慣 行法である EC (electric conductivity) 制御法で生じる培養 液組成の変動や廃培養液などの問題解決, ならびに生育

2006 年 1 月 6 日受付

2007 年 6 月 8 日受理

Corresponding author: Masaaki Kirimura (kirimura@cc.miyazaki-u.ac.jp)
促進や増収を目的とした培養液のイオン濃度制御法について 研究を進めてきた. その結果, EC 制御法とイオン濃度制御 法の統合によるシステムの低コスト化と省力化を両立させた Integrated IonAdjuster System ( 以下 IIAS) の開発に至っ た ${ }^{1)}$. さらにIIAS を含むイオン濃度制御法に関する一連の研 究の結果, 培養液中の各イオン濃度を長期にわたり連続的に 制御することで増収が可能となった ${ }^{1)}$. IIAS による培養液管 理方法は以下のようなものである. 培養液管理の当初は EC 制御により培養液濃度を自動で制御し, 濃厚液がある量以 下まで減る, または枯渇すると夕ンクから培養液をサンプリング 
し，培養液中の各成分濃度を測定する. 次に, 供給した肥 料量や培養液濃度の分析結果, 培養液量のデー夕から得ら れた植物体による養分吸収量を考慮した濃厚液作成に必要 な成分量を, 初回の補正は First Calculation, 二回目以降 の補正は Second Calculation により算出する. さらに, その 結果から肥料計算プログラム IonAdjusterによって濃厚液作 成に必要な肥料の種類と量を算出する. 最後にその結果に 従って濃厚液を作成し, EC 制御を再開する. ただし, 濃厚 液の枯渇前に補正を開始する際には, 当該濃厚液の残量と 組成, 濃度を考慮して新たな濃厚液を設計する必要があり, かなり複雑な作業が要求される. 従って, 本実験では操作を 簡略化するため, 濃厚液の枯渇後に培養液のサンプリングを 行った.

培養液の $\mathrm{pH}$ は各養分の有効性に大きな影響を及ぼすた め, これまでにも $\mathrm{pH}$ 制御に関して多くの研究が行われてき た $^{2)}$. $\mathrm{pH}$ 制御法としてはイオン交換樹脂による制御 ${ }^{3)}$, 酸とア ルカリによる自動制御 ${ }^{4,5)}, \mathrm{NH}_{4}-\mathrm{N} /$ Total-N による制御 ${ }^{6)}$ など がある. しかし, イオン交換樹脂を用いた $\mathrm{pH}$ 制御は実験規 模では可能であったが, コストや目詰まりなどの問題のため普 及しておらず, また培養液の $\mathrm{NH}_{4}-\mathrm{N} /$ Total-N による $\mathrm{pH}$ 制御 は未だ研究段階であり確立されていない. そのため現在一般 的に酸やアルカリを用いた $\mathrm{pH}$ 制御が行われているが, 酸や アルカリに含まれる成分によって培養液中のイオンバランスが 崩れる可能性や薬品の取り扱いに危険を伴うという問題があ る.

前報 ${ }^{1)}$ の IIAS を用いたキュウリ栽培では, $\mathrm{NH}_{4} \mathrm{-N}$ の供給 方法によって培養液の $\mathrm{pH}$ を制御できる可能性が示された。 IIAS によって培養液管理を行うと, 対象イオンの吸収量の増 加率が該当イオンの次期の供給量に反映されるため, 供給し た $\mathrm{NH}_{4}-\mathrm{N}$ が次回の濃厚液調製時までに全て吸収されると仮 定した場合, $\mathrm{NH}_{4}-\mathrm{N}$ の供給量は理論的には指数関数的に増 加してしまい, $\mathrm{pH}$ 低下の要因となる. 従って IIAS をより確か なものとするためには, 作物種に応じた新たな培養液組成や 生育に伴い変化する養分吸収パターンに応じた培養液管理 法の検討が必要と考えられる.

本報では, 培養液の $\mathrm{pH}$ に大きな影響を及ぼす $\mathrm{NH}_{4}-\mathrm{N}$ に 着目し, 初期培養液の $\mathrm{NH}_{4}-\mathrm{N}$ 濃度の違いが培養液 $\mathrm{pH}$ の
変動に及ぼす影響ならびに IIAS における $\mathrm{NH}_{4}-\mathrm{N}$ の供給方 法と培養液の $\mathrm{pH}$ 制御方法の検討結果について報告する。

\section{実験1. キュウリ水耕栽培における初期培養液の $\mathrm{NH}_{4}-\mathrm{N}$ 濃度} が $\mathrm{NH}_{4}$ - $\mathrm{N}$ 吸収速度と培養液 $\mathrm{pH}$ 変動に及ぼす影響

本実験では培養液 $\mathrm{pH}$ の安定化を図るため, キュウリ栽培 における初期培養液の $\mathrm{NH}_{4}-\mathrm{N}$ 濃度の違いが $\mathrm{NH}_{4}-\mathrm{N}$ 吸収速 度と培養液 $\mathrm{pH}$ の変動, 植物体の成長に及ぼす影響につい て調查を行い, 初期培養液の $\mathrm{NH}_{4}-\mathrm{N}$ 濃度の妥当な設定值 および培養液の $\mathrm{NH}_{4}-\mathrm{N}$ 濃度制御による培養液の $\mathrm{pH}$ 制御の 可能性について検討した.

材料および方法

キュウリ (Cucumis sativus L.) ‘アルファー節成’ ( 久留米 原種育成会) を供試し, 2003 年 5 月 2 日に播種し, 子葉展 開まで $28^{\circ} \mathrm{C}$ 恒温器内で管理した. 子葉展開後の 5 月 15 日に シクスライトハウス内に設置した $60 \mathrm{~cm} \times 30 \mathrm{~cm} \times 20 \mathrm{~cm}$ の容 器に浮かせた発泡スチロールパネルに移植し, 本葉が 3 枚 展開するまで湛液育苗した. 培養液は $1 / 2$ 単位大塚 SA 処 方 (大塚化学) とし, エアーポンプによって曝気を行った. 培 養液の $\mathrm{NH}_{4}-\mathrm{N}$ 濃度を $0 \mathrm{mg} l^{-1}, 4 \mathrm{mg} l^{-1}, 8 \mathrm{mg} l^{-1}, 16 \mathrm{mg}$ $l^{-1}$ の 4 段階とした実験区を設け, その他の要素は大塚 SA 処方を目標值として IonAdjusterにより必要な肥料量を算出 し, 多量要素 (Table 1) と微量要素 (Table 2) を共に単肥 $\left(\mathrm{NH}_{4} \mathrm{NO}_{3}, \mathrm{NH}_{4} \mathrm{H}_{2} \mathrm{PO}_{4},\left(\mathrm{NH}_{4}\right)_{2} \mathrm{SO}_{4}, \mathrm{KH}_{2} \mathrm{PO}_{4}, \mathrm{Ca}\left(\mathrm{NO}_{3}\right)_{2}\right.$. $4 \mathrm{H}_{2} \mathrm{O}, \mathrm{KNO}_{3}, \mathrm{MgSO}_{4} \cdot 7 \mathrm{H}_{2} \mathrm{O}, \mathrm{H}_{3} \mathrm{BO}_{3}, \mathrm{MnCl}_{2} \cdot 4 \mathrm{H}_{2} \mathrm{O}$, $\mathrm{ZnSO}_{4} \cdot 7 \mathrm{H}_{2} \mathrm{O}, \mathrm{CuSO}_{4} \cdot 5 \mathrm{H}_{2} \mathrm{O}, \mathrm{NaMoO}_{4} \cdot 2 \mathrm{H}_{2} \mathrm{O}$, EDTA$\mathrm{Fe})$ を用いて培養液を調製した. 6 月 1 日に $1 / 5000$ a ワグネ ルポット 1 個 ( 培養液量 $3 l$ ) あたりに 1 個体ずつ, 各区 4 個 体を定植し, エアーポンプにより常時曝気を行い, 調査を 6 月 6 日まで行った. 初期培養液の $\mathrm{pH}$ は $6.35 \pm 0.05$ であった. また, 硝酸化成菌などの影響 ${ }^{7}$ を考慮するために, $\mathrm{NH}_{4}-\mathrm{N}$ 濃度を $8 \mathrm{mg} l^{-1}$ とした培養液で植物体を定植しない区も設け 調査した. 栽培期間中の培養液量の推移および吸水量は水 深を測定することにより, 毎日測定した. 栽培期間中に吸収さ れた無機成分の量は, 栽培試験終了後に培養液量を初期 值にあわせ, 栽培開始時と栽培終了時の各成分の濃度と培 養液量から算出した. 培養液中の無機成分分析は高速液

Table 1 Macronutrient composition of the nutrient solutions $\left(\mathrm{mg} l^{-1}\right)$ on a theoretical basis calculated with IonAdjuster

\begin{tabular}{lccccccc}
\hline \multicolumn{1}{c}{ Treatment } & $\mathrm{NO}_{3}-\mathrm{N}$ & $\mathrm{NH}_{4}-\mathrm{N}$ & $\mathrm{PO}_{4}-\mathrm{P}$ & $\mathrm{K}$ & $\mathrm{Ca}$ & $\mathrm{Mg}$ & $\mathrm{SO}_{4}-\mathrm{S}$ \\
\hline $\mathrm{SA}^{\mathrm{z}}$ & 237.0 & 8.0 & 45.8 & 398.5 & 164.4 & 36.2 & 47.3 \\
$0 \mathrm{mg} l^{-1}$ & 241.3 & 0.0 & 45.8 & 406.3 & 166.6 & 38.0 & 50.1 \\
$4 \mathrm{mg} l^{-1}$ & 241.0 & 4.0 & 46.0 & 400.0 & 164.0 & 38.0 & 50.1 \\
$8 \mathrm{mg} l^{-1}$ & 240.8 & 7.9 & 46.2 & 393.6 & 161.4 & 38.0 & 50.1 \\
$16 \mathrm{mg} l^{-1}$ & 240.2 & 15.6 & 46.7 & 381.1 & 156.2 & 38.0 & 50.1 \\
\hline “ “Otsu
\end{tabular}

z "Otsuka SA" prescription 
Table 2 Micronutrient composition of the nutrient solution $\left(\mathrm{mg} l^{-1}\right)$

\begin{tabular}{ccccccc}
\hline \hline & $\mathrm{B}$ & $\mathrm{Mn}$ & $\mathrm{Zn}$ & $\mathrm{Cu}$ & $\mathrm{Mo}$ & $\mathrm{Fe}$ \\
\hline Micronutrient & 0.5 & 0.5 & 0.05 & 0.02 & 0.01 & 3.0 \\
\hline
\end{tabular}

体クロマトグラフ (東ソー ) で行い, カチオンには IC-Cation I / II -HR カラム (東ソー ), アニオンには PCI-201S カラム （東覀ディーケーケー）を用いた. 培養液の $\mathrm{pH}$ と EC 值の

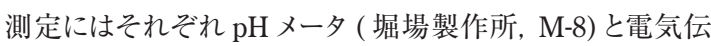
導度計 (東亜ディーケーケー, TCX-90i) を用いた. 6 月 6 日 に地上部新鮮重, 地上部乾物重, SPAD 值 (コニカミノルタ センシング, 葉緑素計 SPAD-502) を測定した. SPAD 值は個 体ごとに異なる 3 枚の葉の先端部を測定した平均値とした. 結果および考察

葉の SPAD 值と植物体の草丈, 新鮮重, 乾物重, 吸水 量, EC 值には各処理区間で有意な差はみられなかった (デー夕略)

培養液の $\mathrm{pH}$ は 6 月 3 日までは有意差 $(\mathrm{P}<0.01)$ がみ られなかったが, 6 月 4 日には $\mathrm{NH}_{4}-\mathrm{N}$ 濃度 $16 \mathrm{mg} l^{-1}$ 区と 8 $\mathrm{mg} l^{-1}$ 区で $\mathrm{NH}_{4}-\mathrm{N}$ 濃度 $0 \mathrm{mg} l^{-1}$ 区よりも有意に低くなり, 6 月 5 日には $\mathrm{NH}_{4}-\mathrm{N}$ 濃度 $16 \mathrm{mg}^{-1}$ 区で $0 \mathrm{mg} l^{-1}$ 区よりも有意 に低く, 初期值よりも 0.95 低い $\mathrm{pH} 5.45$ となり, 最低值となっ た (Fig. 1). 6 月 6 日には $\mathrm{NH}_{4}-\mathrm{N}$ 濃度 $16 \mathrm{mg} l^{-1}$ 区の $\mathrm{pH}$ が 他の全ての区に比べ有意に低くなった，また，初期培養液の $\mathrm{NH}_{4}-\mathrm{N}$ 濃度が高い区ほど $\mathrm{pH}$ の低下幅が大きかった. 6 月 6 日には全ての区で前日よりも $\mathrm{pH}$ が上昇する傾向がみられた が, これは植物体による養分吸収によって培養液の $\mathrm{NH}_{4}-\mathrm{N}$ 濃度が低下したため, $\mathrm{NH}_{4}-\mathrm{N}$ の吸収量が減少したことで $\mathrm{pH}$ が上昇したと推測される (Fig. 2). このことは $\mathrm{NH}_{4}-\mathrm{N}$ が優先 的に吸収される場合は培養液の $\mathrm{pH}$ が低下し, $\mathrm{NH}_{4}-\mathrm{N}$ が吸 収し尽くされると, $\mathrm{pH}$ は変化しないかあるいはむしろ上昇する という報告 ${ }^{8)}$ と一致した，その他の成分の濃度は上昇する傾 向がみられた (デー夕略).

培養液の $\mathrm{NH}_{4}-\mathrm{N}$ の初期濃度に対する 5 日間の 1 個体当 たり $\mathrm{NH}_{4}-\mathrm{N}$ と $\mathrm{PO}_{4}-\mathrm{P}$ の吸収量, 培養液 $\mathrm{pH}$ の変動值のピア ソンの積率相関係数はそれぞれ，0.960, $-0.884,-0.824$ と なり, 無相関の検定では $\mathrm{P}<0.01$ で有意に相関がみられた (Table 3). 従って, 初期培養液の $\mathrm{NH}_{4}-\mathrm{N}$ 濃度が高くなる,
または $\mathrm{NH}_{4}-\mathrm{N}$ 吸収量が増加するにつれ, $\mathrm{PO}_{4}-\mathrm{P}$ の吸収が 抑制され，かつ培養液の $\mathrm{pH}$ の低下幅が大きくなる可能性が あると考えられる. 一般的に適性範囲内の $\mathrm{pH}$ の培養液で は, $\mathrm{pH}$ が低いほど培養液中の $\mathrm{PO}_{4}-\mathrm{P}$ の有効性は高く $\mathrm{PO}_{4}-\mathrm{P}$ の吸収量は増加するはずであるが ${ }^{9,10)}$, 本実験でみられる $\mathrm{PO}_{4}-\mathrm{P}$ の吸収量の減少はピアソンの積率相関係数の結果か ら, 培養液の $\mathrm{pH}$ よりむしろ $\mathrm{NH}_{4}-\mathrm{N}$ 吸収量が大きく影響した と推測される.

次に, 培養液の $\mathrm{NH}_{4}-\mathrm{N}$ 濃度と $\mathrm{NH}_{4}-\mathrm{N}$ 吸収速度の関係

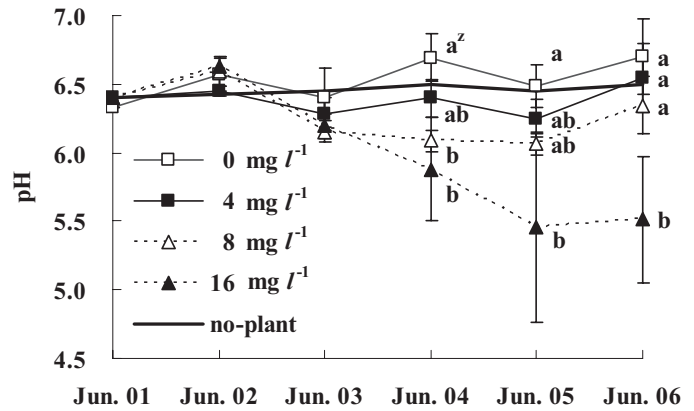

Fig. 1 Changes in $\mathrm{pH}$ value of the nutrient solutions of various $\mathrm{NH}_{4}-\mathrm{N}$ concentration. ${ }^{2}$ Different letters within days represent significant differences by LSD test (1\% level).

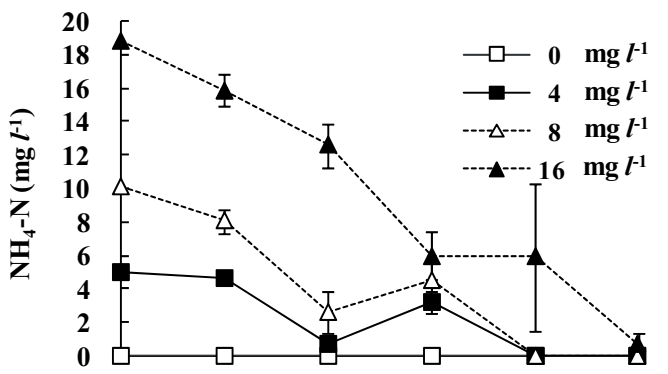

Jun. 01 Jun. 02 Jun. 03 Jun. 04 Jun. 05 Jun. 06

Fig. 2 Changes in $\mathrm{NH}_{4}-\mathrm{N}$ concentration in the nutrient solutions of each treatment.

Table 3 The correlation coefficient and the result of the uncorrelation test of $\mathrm{NH}_{4}-\mathrm{N}$ concentration $\left(\mathrm{mg} l^{-1}\right)$, amount of $\mathrm{NH}_{4}-\mathrm{N}$ absorption $\left(\mathrm{mg}\right.$ plant $\left.{ }^{-1}\right)$, amount of $\mathrm{PO}_{4}-\mathrm{P}$ absorption $(\mathrm{mg}$ plant $^{-1}$ ), and variation of $\mathrm{pH}$.

\begin{tabular}{|c|c|c|c|c|c|c|c|}
\hline & \multicolumn{2}{|c|}{ N $\mathrm{NH}_{4}-\mathrm{N}$ concentration } & \multicolumn{2}{|c|}{$\mathrm{NH}_{4}-\mathrm{N}$ absorption } & \multicolumn{2}{|c|}{$\mathrm{PO}_{4}-\mathrm{P}$ absorption } & pH variation \\
\hline $\mathrm{NH}_{4}-\mathrm{N}$ concentration & 1.000 & & & & & & \\
\hline $\mathrm{NH}_{4}-\mathrm{N}$ absorption & 0.960 & $* *^{2}$ & 1.000 & & & & \\
\hline $\mathrm{PO}_{4}-\mathrm{P}$ absorption & -0.884 & $* *$ & -0.847 & $* *$ & 1.000 & & \\
\hline $\mathrm{pH}$ variation & -0.824 & $* *$ & -0.865 & ** & 0.745 & $* *$ & 1.000 \\
\hline
\end{tabular}

${ }^{\mathrm{z}}$ Population correlation coefficient are not 0 at $\mathrm{P}<0.01$ level by uncorrelation test. 
Table 4 Standard value of model of relation between the initial concentration of $\mathrm{NH}_{4}-\mathrm{N}$ and the absorption rate $\left(\mathrm{mg}\right.$ plant $\left.{ }^{-1} \mathrm{day}^{-1}\right)$.

\begin{tabular}{cccc}
\hline \hline & Formula & $\mathrm{R}^{2}$ & $\mathrm{AIC}^{2}$ \\
\hline Gompertz curve & $y=a e^{-b c^{x}}$ & 1.000 & -104.651 \\
Cubic curve & $y=a x^{3}+b x^{2}+c x+d$ & 1.000 & -65.264 \\
Logistic curve & $y=\frac{a}{1+b e^{-c x}}$ & 1.000 & -52.001 \\
Ogive & $y=a(1-(1+b x)) e^{-b x}$ & 0.904 & -5.370 \\
Rectangular hyperbola & $y=\frac{a x}{b+x}$ & 0.853 & -3.679 \\
Threshold curve & $y=\frac{a\left(\frac{x}{b}\right)^{c}}{1+(x+b)^{c}}$ & 0.903 & -3.343 \\
Quadric curve & $y=a x^{2}+b x+c$ & 0.867 & -2.078 \\
\hline
\end{tabular}

${ }^{\mathrm{z}}$ Akaike's information criterion.

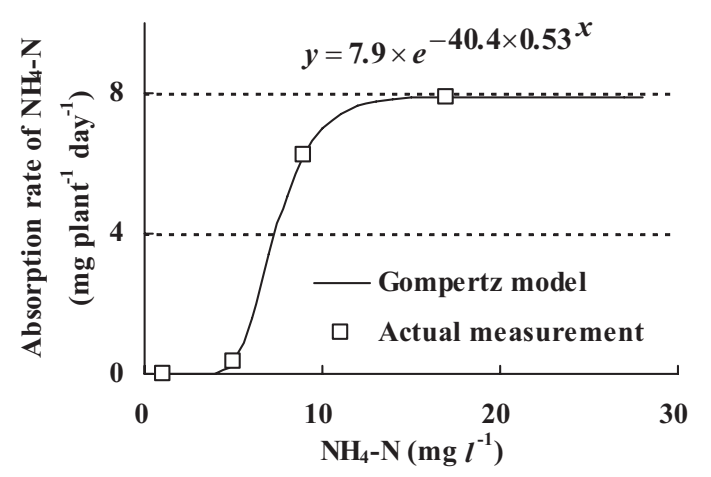

Fig. 3 Gompertz model of relation between the initial concentration of $\mathrm{NH}_{4}-\mathrm{N}$ and $\mathrm{NH}_{4}-\mathrm{N}$ absorption rate $\left(\mathrm{mg}\right.$ plant $^{-1}$ day $\left.^{-1}\right)$.

を明らかにするため, 培養液の初期 $\mathrm{NH}_{4}-\mathrm{N}$ 濃度を説明変 数 $(x$ 軸 $)$, 定植 1 日後の $\mathrm{NH}_{4}-\mathrm{N}$ 濃度の変化から求めた吸 収速度 $\left(\mathrm{mg}\right.$ plant $\left.^{-1} \mathrm{day}^{-1}\right)$ を被説明変数 $(y$ 軸) とした最適 曲線を求めた. 得られたデータをゴンペルツ曲線とロジステイッ ク曲線, 直角双曲線 (Michaelis Menten 式), S 字曲線, 閾值反応曲線, 二次曲線, 三次曲線にあてはめ, 決定係 数 $\mathrm{R}^{2}$ と赤池弘次氏の情報量基準 $\mathrm{AIC}^{11 \sim 13)}$ で適合度を評 価した結果, ゴンペルツ曲線が最も適合していると考えられた (Table 4). 吸収速度は培養液の $\mathrm{NH}_{4}-\mathrm{N}$ 濃度が高くなるにつ れて急激に上昇し, 最大值は $7.9 \mathrm{mg}$ plant $^{-1}$ day $^{-1}$ になると 予測される (Fig. 3). 以上の結果, $\mathrm{NH}_{4}-\mathrm{N}$ 濃度 $16 \mathrm{mg} l^{-1}$ 以 下では $\mathrm{NH}_{4}-\mathrm{N}$ 吸収速度が $\mathrm{NH}_{4}-\mathrm{N}$ 濃度に大きく影響される, つまり, $\mathrm{NH}_{4}-\mathrm{N}$ 濃度が少しでも変化すれば $\mathrm{NH}_{4}-\mathrm{N}$ 吸収速度 が大きく変化するということであり, 植物体による吸収速度を 考慮して養分供給量を補正する IIAS では $\mathrm{NH}_{4}-\mathrm{N}$ の供給量 と吸収量に差が生じ, 培養液中の $\mathrm{NH}_{4}-\mathrm{N}$ 濃度を $16 \mathrm{mg} l^{-1}$
以下で一定に維持することは困難であると考えられる. また, $\mathrm{NH}_{4}-\mathrm{N}$ 濃度の維持を目的として $\mathrm{NH}_{4}-\mathrm{N}$ の供給量を増加させ ると $\mathrm{NH}_{4}-\mathrm{N}$ が多量に供給され, 培養液の $\mathrm{pH}$ が異常に低下 することが考えられる. 従って, $\mathrm{NH}_{4}-\mathrm{N}$ の濃度制御により培 養液の $\mathrm{pH}$ を制御することは現実的でないといえる. さらに, $\mathrm{NH}_{4}-\mathrm{N}$ の吸収量と吸収速度は培養液量や個体数, 株の大き さ, 環境要因, 生育段階に左右されるため, $\mathrm{pH}$ 制御を目的と した $\mathrm{NH}_{4}-\mathrm{N}$ 濃度制御を適切に行うことは非常に煩雑と考えら れる.

実験2. IIASを用いたキュウリ水耕栽培における $\mathrm{NH}_{4}-\mathrm{N}$ 供給方法の検討

IIAS を用いた栽培試験の結果, IIAS の特性から $\mathrm{NH}_{4}-\mathrm{N}$ が連続的に過剩に供給・吸収されるため培養液の $\mathrm{pH}$ が低 下する傾向がみられた ${ }^{1)}$. また, イオン濃度制御キュウリ養液 栽培に関するこれまでの研究結果から, 大塚 SA 処方を用い る場合, 培養液の $\mathrm{pH}$ 低下防止には培養液の $\mathrm{NH}_{4}-\mathrm{N}$ 濃度 のみを大塚 SA 処方より低く設定し, その供給量を間接的に 制限する方法が有効であり, さらに $\mathrm{NO}_{3}-\mathrm{N}$ 濃度を大塚 $\mathrm{SA}$ 処方の值に制御し $\mathrm{NH}_{4}-\mathrm{N}$ 供給量が $\mathrm{NO}_{3}-\mathrm{N}: \mathrm{NH}_{4}-\mathrm{N}=30: 1$ のときに培養液の $\mathrm{pH}$ の変化が小さかったことから, 濃厚液 による $\mathrm{NH}_{4}-\mathrm{N}$ の供給方法は濃度よりも $\mathrm{NO}_{3}-\mathrm{N}$ との比率に 基づいて行うべきであると提案した ${ }^{14)}$. また実験 1 の結果, $\mathrm{NH}_{4}-\mathrm{N}$ 濃度制御は非常に困難であることが示された. 従って 本実験では IIAS によるキュウリ養液栽培において培養液 $\mathrm{pH}$ の安定化を図るため, 追加供給する $\mathrm{N}$ 源の $\mathrm{NO}_{3}-\mathrm{N}: \mathrm{NH}_{4}-\mathrm{N}$ に着目した $\mathrm{NH}_{4}-\mathrm{N}$ 供給方法を比較検討した

材料および方法

栽培は実験 1 に準じ, キュウリ (Cucumis sativus L.) ‘翠 星節成 2 号' (久留米原種育成会) を供試し, 2003 年 8 月 18 日に播種, 9 月 1 日から湛液育苗した. 9 月 24 日にベッド 
$(400 \mathrm{~cm} \times 36 \mathrm{~cm} \times 21 \mathrm{~cm}$, 地上高 $55 \mathrm{~cm}, 1$ 列 $)$ に株間 50 $\mathrm{cm}$ で 1 ベッド当たり 6 個体ずつ定植した. 1 処理は各区 1 べ ッドとした. 整枝方法は力枝 2 本の子づるつる下げ誘引とし, 主枝を 20 節で摘心した. 基本培養液処方は大塚 $\mathrm{SA}$ 処方 とし, 実験 1 で使用した単肥に加え $\mathrm{K}_{2} \mathrm{SO}_{4}$ を用いて調製し た. 各区の培養液量 (ベッド内+タンク内 ) は $300 l$ で, ポン プの吐出口直後に設けたバルブを調整し培養液の一部を夕ン ク内へ落下させることで夕ンク内培養液の溶存酸素濃度を保 った. 培養液管理法は手動イオン濃度制御法である Popular Edition of Intelligent System ( 以下 PEIS) ${ }^{15)}$ と IIAS を用い た. IIAS では培養液の $\mathrm{NH}_{4}-\mathrm{N}$ の設定值を $8 \mathrm{mg} l^{-1}$ とした区 (以下, IIAS normal), 追加供給する $\mathrm{N}$ 源を $\mathrm{NO}_{3}-\mathrm{N}: \mathrm{NH}_{4}-\mathrm{N}$ $=30: 1$ とした区 ( 以下, IIAS 30: 1), 初期の制御は IIAS 30: 1 区と同様に行い, 培養液の $\mathrm{pH}$ が 5.5 から 6.5 の間とな るように, 培養液の $\mathrm{pH}$ の変化に応じて栽培者の判断により
濃厚液の $\mathrm{NH}_{4}-\mathrm{N}$ の比率を管理するファジー管理区 ( 以下, IIAS fuzzy) を設け, 計 4 区にて比較検討した. 初期濃厚液 は大塚 SA 処方とし, IIAS の濃厚液調製間隔は 14 日とした. PEIS の培養液の補正は週に 1 回行った. IIAS の EC 值は $2.4 \mathrm{dS} \mathrm{m}^{-1}$ の定值制御とし, EC 制御には SS 式肥料管理機 (シーアイ化成, AS-3) を用いた. 調査は培養液の成分濃度 と $\mathrm{pH}, \mathrm{EC}$ 值, 収量について行った. 果実は果長 $22 \mathrm{~cm}$ 前 後で収穫し, 10 月 23 日から 11 月 21 日まで収穫を行った。 結果および考察

IIAS の EC 制御は 9 月 25 日から開始した. IIAS の濃厚 液作成に必要な成分量の計算は Second Calculation ${ }^{1)}$ の不 具合や精度が低いなどの理由から全て First Calculationに よって行った. 濃厚液の調製と培養液の補正の回数は IIAS normal が 4 回, IIAS30:1 が 5 回, IIAS fuzzy が 5 回, PEIS が 7 回であった (Table 5). PEIS の培養液補正回数

Table 5 The amount of fertilizer used for making stock solution or correcting nutrient solution $(\mathrm{g})$.

\begin{tabular}{|c|c|c|c|c|c|c|c|c|c|c|}
\hline Treatment & Date & $\mathrm{NH}_{4} \mathrm{NO}_{3}$ & $\mathrm{NH}_{4} \mathrm{H}_{2} \mathrm{PO}_{4}$ & $\left(\mathrm{NH}_{4}\right)_{2} \mathrm{SO}_{4}$ & $\mathrm{KH}_{2} \mathrm{PO}_{4}$ & $\mathrm{Ca}\left(\mathrm{NO}_{3}\right)_{2} \cdot 4 \mathrm{H}_{2} \mathrm{O}$ & $\mathrm{KNO}_{3}$ & $\mathrm{~K}_{2} \mathrm{SO}_{4}$ & $\mathrm{MgSO}_{4} \cdot 7 \mathrm{H}_{2} \mathrm{O}$ & $\begin{array}{c}\text { Total } \\
\text { Weight }\end{array}$ \\
\hline \multirow{4}{*}{$\begin{array}{c}\text { IIAS } \\
\text { normal }\end{array}$} & Sep. 25 & 0.3 & 1.0 & 0.0 & 2.9 & 18.0 & 18.5 & 0.0 & 7.0 & 47.6 \\
\hline & Oct. 16 & 9.5 & 4.7 & 0.2 & 0.0 & 7.7 & 0.0 & 0.0 & 0.0 & 22.1 \\
\hline & Oct. 19 & 82.6 & 26.3 & 2.4 & 0.0 & 61.2 & 0.0 & 0.0 & 0.0 & 172.6 \\
\hline & Oct. 28 & 0.0 & 0.0 & 0.0 & 0.1 & 165.8 & 161.2 & 0.0 & 25.7 & 352.8 \\
\hline \multirow{4}{*}{$\begin{array}{l}\text { IIAS } \\
30: 1\end{array}$} & Sep. 25 & 0.3 & 1.0 & 0.0 & 2.9 & 18.0 & 18.5 & 0.0 & 7.0 & 47.6 \\
\hline & Oct. 16 & 0.0 & 0.2 & 0.0 & 8.7 & 16.0 & 0.0 & 0.0 & 0.0 & 25.0 \\
\hline & Oct. 23 & 0.9 & 0.7 & 0.0 & 6.8 & 67.8 & 9.2 & 0.0 & 3.5 & 88.9 \\
\hline & Oct. 30 & 0.0 & 2.1 & 3.5 & 146.3 & 179.4 & 0.0 & 8.9 & 25.9 & 366.1 \\
\hline \multirow{5}{*}{$\begin{array}{l}\text { IIAS } \\
\text { fuzzy }\end{array}$} & Sep. 25 & 0.3 & 1.0 & 0.0 & 2.9 & 18.0 & 18.5 & 0.0 & 7.0 & 47.6 \\
\hline & Oct. 09 & 0.0 & 0.1 & 0.3 & 7.8 & 43.4 & 8.7 & 21.3 & 0.0 & 81.6 \\
\hline & Oct. 19 & 1.2 & 0.7 & 0.0 & 6.5 & 37.1 & 23.3 & 0.0 & 0.0 & 68.9 \\
\hline & Oct. 28 & 21.7 & 13.3 & 0.0 & 59.4 & 215.8 & 99.8 & 0.0 & 13.9 & 423.9 \\
\hline & Nov. 13 & 0.0 & 6.6 & 0.5 & 88.9 & 203.3 & 9.3 & 6.1 & 35.4 & 350.1 \\
\hline \multirow{7}{*}{ PEIS } & Oct. 02 & 1.5 & 10.4 & 0.0 & 0.0 & 20.5 & 0.0 & 0.0 & 4.1 & 44.4 \\
\hline & Oct. 09 & 7.3 & 0.0 & 3.0 & 0.0 & 26.9 & 16.3 & 14.1 & 0.0 & 67.7 \\
\hline & Oct. 16 & 13.3 & 0.0 & 0.0 & 0.0 & 0.0 & 0.0 & 0.0 & 0.0 & 13.3 \\
\hline & Oct. 23 & 0.0 & 3.9 & 6.7 & 0.0 & 41.5 & 67.5 & 0.0 & 0.0 & 119.5 \\
\hline & Oct. 30 & 4.3 & 14.6 & 0.0 & 22.9 & 68.5 & 17.1 & 0.0 & 9.3 & 136.6 \\
\hline & Nov. 06 & 11.4 & 3.5 & 0.0 & 25.6 & 42.6 & 39.2 & 0.0 & 7.5 & 129.8 \\
\hline & Nov. 13 & 9.2 & 0.0 & 0.0 & 0.0 & 25.7 & 23.0 & 0.0 & 6.9 & 64.9 \\
\hline
\end{tabular}

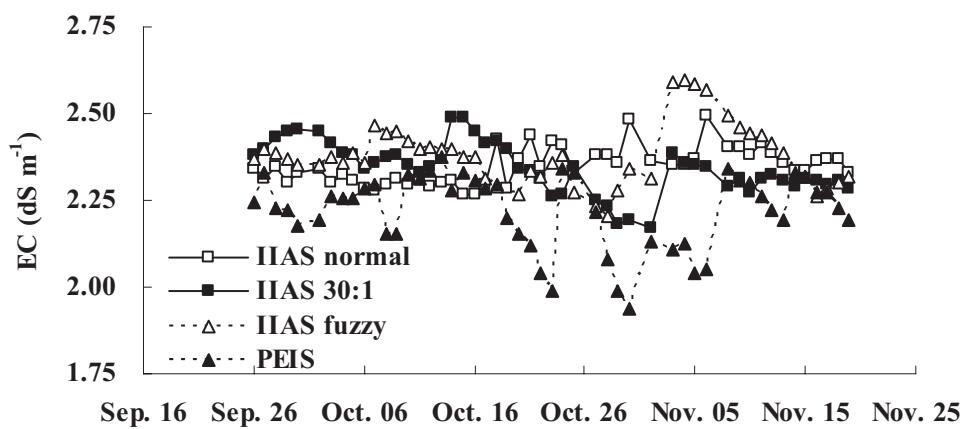

Fig. 4 Changes in electric conductivity of the nutrient solutions controlled by various methods. 
Table 6 The amount of element used for making the stock solution or correcting nutrient solution $(\mathrm{g})$.

\begin{tabular}{lcrrrrrrr}
\hline \hline Treatment & $\mathrm{NO}_{3}-\mathrm{N}^{-\mathrm{NH}_{4}-\mathrm{N}}$ & $\mathrm{NO}_{3}-\mathrm{N}$ & $\mathrm{NH}_{4}-\mathrm{N}$ & $\mathrm{PO}_{4}-\mathrm{P}$ & \multicolumn{1}{c}{$\mathrm{K}$} & $\mathrm{Ca}$ & $\mathrm{Mg}$ & $\mathrm{SO}_{4} \mathrm{~S}$ \\
\hline IIAS normal & $3.8: 1$ & 76.90 & 20.47 & 10.50 & 81.55 & 46.51 & 4.21 & 6.19 \\
IIAS 30:1 & $26.3: 1$ & 43.71 & 1.66 & 39.38 & 73.06 & 51.25 & 4.57 & 8.48 \\
IIAS fuzzy & $14.2: 1$ & 104.76 & 7.38 & 46.48 & 151.77 & 98.05 & 8.22 & 16.01 \\
PEIS & $4.2: 1$ & 58.01 & 13.92 & 20.86 & 83.68 & 36.60 & 3.62 & 6.38 \\
\hline
\end{tabular}

に比べ IIAS の濃厚液作成回数を減らせたが, 濃厚液調製 間隔が予定よりも短くなった. その原因は肥料計算を行った First Calculation が養分吸収量の増加に対応できなかった ためである. 今後 First Calculation に代わる肥料計算法を 検討する必要がある.

培養液の EC 值は IIAS では $2.4 \mathrm{dS} \mathrm{m}^{-1}$ 前後で推移した が, PEIS では培養液の補正前に低下し, 特に養分吸収量 の多い生育中期には顕著であった (Fig. 4).

濃厚液または培養液補正で追加供給した各成分の総量 は, 生育後期に濃厚液の調製を行った IIAS fuzzy で多くな った (Table 6). 供給した肥料の各成分総量のうち, N 源に 占める $\mathrm{NH}_{4}-\mathrm{N}$ の比率を比較すると IIAS normal が最も高く, IIAS 30：1 が最も低かった．また， $\mathrm{NH}_{4}-\mathrm{N}$ 供給量が多い区 では $\mathrm{PO}_{4}-\mathrm{P}$ 供給量が少なくなる傾向がみられた ( 相関係数

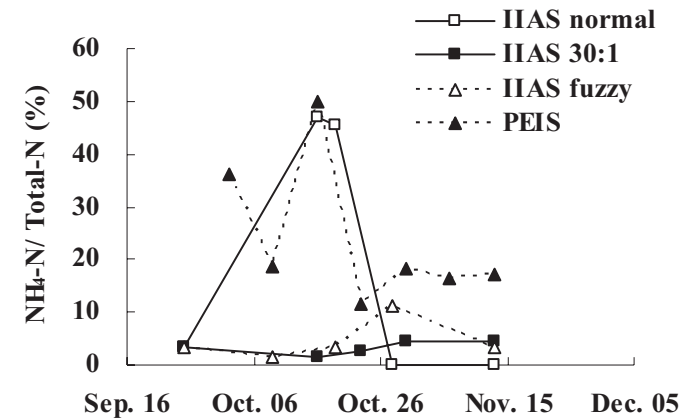

Fig. 5 Changes of the percentage of $\mathrm{NH}_{4}-\mathrm{N}$ in total supplied $\mathrm{N}$ sources.
-0.889). これは培養液の $\mathrm{NH}_{4}-\mathrm{N}$ 吸収量が高くなるにつれ $\mathrm{PO}_{4}-\mathrm{P}$ 吸収量が減少した実験 1 の結果を裏付けている.

栽培終了日を考慮していなかったため IIAS の濃厚液は栽 培終了時に残存していた. 従って, 栽培期間中に濃厚液を使 い切ってしまうためには, 栽培終了予定日を考慮する必要が ある. またIIAS の濃厚液調製間隔は当初 14 日を目標として いたが, ばらつきがあったため養分吸収量予測の改善が必 要である.

供給した $\mathrm{N}$ 源のうち $\mathrm{NH}_{4}-\mathrm{N}$ が占める割合 (\% ) は, IIAS normal と PEIS では約 50\%まで大幅に上昇し, IIAS fuzzy では若干上昇し, IIAS 30：1では設定通り約 3\%で推移した (Fig. 5). IIAS normal の pH が 10 月 27 日に 4.63 まで低下 したため, 10 月 28 日に調製した濃厚液から $\mathrm{NH}_{4}-\mathrm{N}$ の供給 を停止したが, 培養液中に $\mathrm{NH}_{4} \mathrm{-N}$ が残存したためしばらくの 間 pH の低下がみられた (Fig. 6).

IIAS normal では, $\mathrm{NH}_{4}-\mathrm{N}$ 濃度が目標值 $\left(8 \mathrm{mg} l^{-1}\right)$ よりも 高い值で推移したが, これは初期の $\mathrm{NH}_{4}-\mathrm{N}$ 吸収量増加率 によって推定し供給した量に見合うだけの吸収がその後続か なかったためと考えられる (Fig. 7). また, IIAS normalでは $\mathrm{NH}_{4}-\mathrm{N}$ 濃度の上昇と同時期に $\mathrm{K}$ 濃度の低下がみられた. こ れは $\mathrm{NH}_{4}-\mathrm{N}$ 吸収量の多かった生育初期には $\mathrm{K}$ 吸収量が比 較的少なく, そのため 10 月 16,19 日に調製した濃厚液に $\mathrm{K}$ が供給されなかったことが原因と考えられた。

IIAS fuzzy では 10 月 28 日の濃厚液調整時まで $\mathrm{pH}$ の上 昇が続いたため, $\mathrm{NO}_{3}-\mathrm{N}: \mathrm{NH}_{4}-\mathrm{N}$ を 30:1 から 10:1に変え, さらに 11 月 13 日には $\mathrm{pH}$ の低下を緩やかにするために濃厚

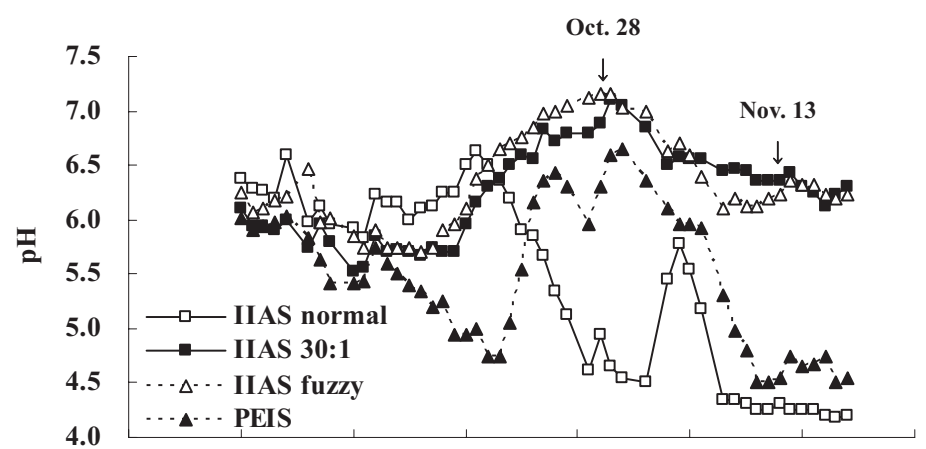

$\begin{array}{llllllll}\text { Sep. } 16 & \text { Sep. } 26 & \text { Oct. } 06 & \text { Oct. } 16 & \text { Oct. } 26 & \text { Nov. } 05 & \text { Nov. } 15 & \text { Nov. } 25\end{array}$

Fig. 6 Changes in $\mathrm{pH}$ of the nutrient solutions controlled by various methods. 

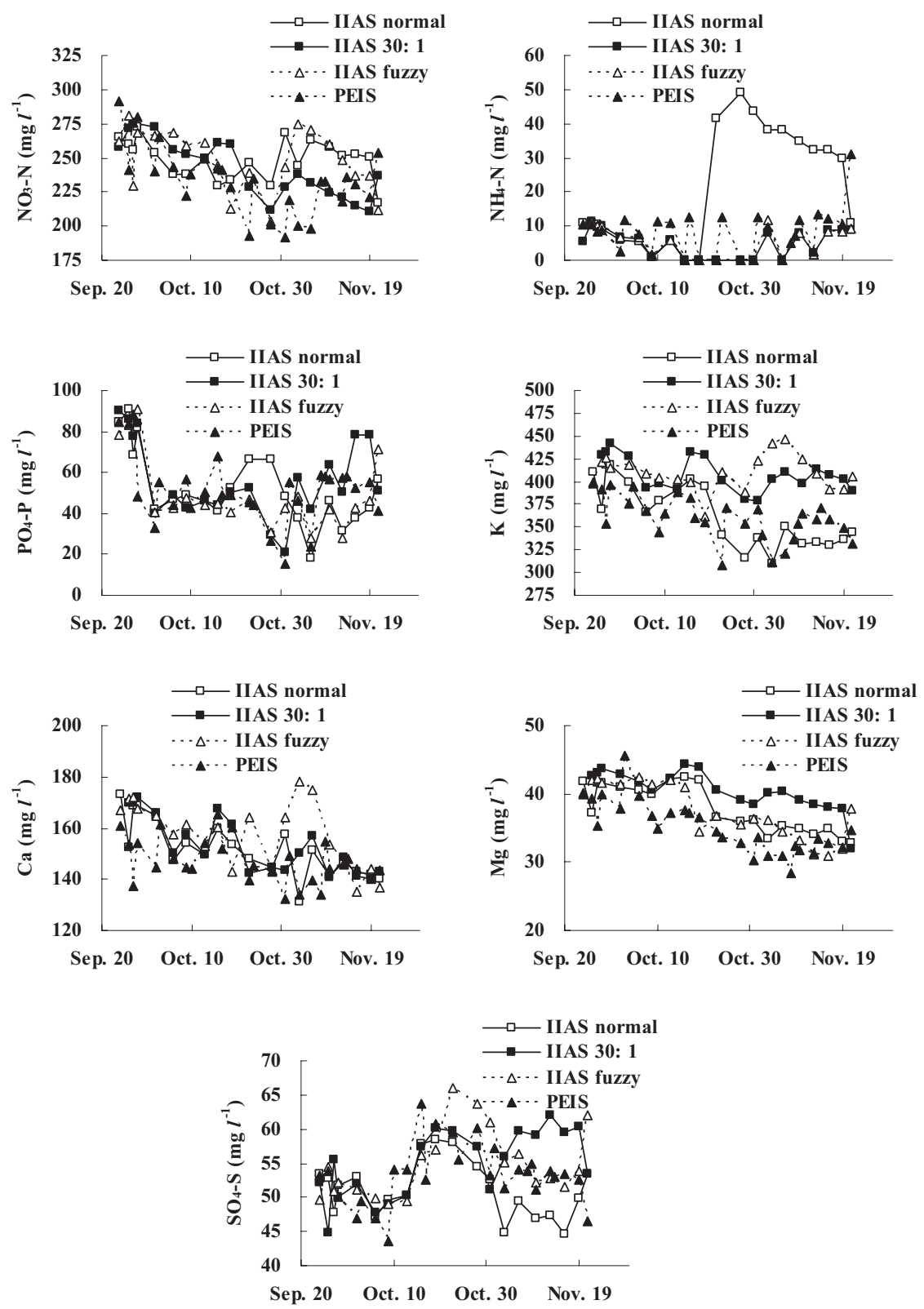

Fig. 7 Changes in macronutrient concentration of the nutrient solutions controlled by various methods.

液の $\mathrm{NO}_{3}-\mathrm{N}: \mathrm{NH}_{4}-\mathrm{N}$ を $20: 1$ に変更した. IIAS $30 ： 1$ と IIAS fuzzy では, 養分吸収が盛んな生育中期に培養液の $\mathrm{pH}$ が 上昇した. この時期に $\mathrm{NH}_{4}-\mathrm{N}$ の供給比率を適度に高めること により，培養液の $\mathrm{pH}$ 上昇を抑制し，適正範囲に制御できれ ば生育促進が見込める。つまり, 生育初期は $\mathrm{NO}_{3}-\mathrm{N}: \mathrm{NH}_{4}-\mathrm{N}$ を $30: 1$ 程度で維持することで培養液の $\mathrm{pH}$ 低下を抑制
し, 生育中期は $\mathrm{NH}_{4}-\mathrm{N}$ の供給比率を高めることで培養液 の $\mathrm{pH}$ 上昇を抑制し, 生育後期には $\mathrm{NO}_{3}-\mathrm{N}: \mathrm{NH}_{4}-\mathrm{N}$ を 30 ： 1 に戻すことで培養液の $\mathrm{pH}$ 低下を抑制できると考えられる. 一方で, 栄養成長期には $\mathrm{NH}_{4}-\mathrm{N}$ がより良く, 生殖成長には $\mathrm{NO}_{3}-\mathrm{N}$ がより良いという報告 ${ }^{16)}$ や, 生育中期から後期が秋か ら冬期にかかる作型で, 弱日照下における草勢を維持するた 
Table 7 Effect of the management of nutrient solution on the marketable yield of cucumber.

\begin{tabular}{lcc}
\hline \hline Treatment & Marketable yield (number plant $^{-1}$ ) \\
\hline IIAS normal & 23.7 & $\mathrm{a}^{\mathrm{z}}$ \\
IIAS 30:1 & 24.3 & $\mathrm{a}$ \\
IIAS fuzzy & 23.5 & $\mathrm{a}$ \\
PEIS & 23.7 & $\mathrm{a}$ \\
${ }^{\mathrm{z}}$ Different letters represent significant differences by LSD test (5\% level).
\end{tabular}

Table 8 Effect of the management of nutrient solution on $\mathrm{NO}_{3}-\mathrm{N}, \mathrm{PO}_{4}-\mathrm{P}$ and $\mathrm{SO}_{4}-\mathrm{S}$ concentration in juice of cucumber fruit $\left(\mathrm{mg} l^{-1}\right)$.

\begin{tabular}{|c|c|c|c|c|c|c|c|}
\hline \multirow{2}{*}{ Treatment } & \multicolumn{3}{|c|}{$\mathrm{NO}_{3}-\mathrm{N}$} & \multicolumn{2}{|r|}{$\mathrm{PO}_{4}-\mathrm{P}$} & \multicolumn{2}{|r|}{$\mathrm{SO}_{4}-\mathrm{S}$} \\
\hline & Oct. 23 & Nov. 05 & Nov. 18 & Oct. 23 & Nov. 05 Nov. 18 & Oct. 23 & Nov. 05 Nov. 18 \\
\hline IIA normal & $267.2 \mathrm{a}^{\mathrm{z}}$ & $468.6 \mathrm{a}$ & $211.5 \mathrm{a}$ & $247.0 \mathrm{a}$ & $497.8 \mathrm{a} \quad 307.3 \mathrm{a}$ & $123.2 \mathrm{~b}$ & $220.2 \mathrm{a} \quad 272.5 \mathrm{a}$ \\
\hline IIA 30:1 & $377.4 \mathrm{a}$ & $401.5 \mathrm{a}$ & $126.6 \mathrm{a}$ & $443.6 \mathrm{a}$ & 207.7 a 497.5 a & $253.2 \mathrm{a}$ & $145.9 \mathrm{a} \quad 215.2 \mathrm{a}$ \\
\hline IIA fuzzy & $295.0 \mathrm{a}$ & $608.1 \mathrm{a}$ & $182.9 \mathrm{a}$ & $446.7 \mathrm{a}$ & 333.7 a 570.7 a & $184.0 \mathrm{ab}$ & 151.3 a 199.9 a \\
\hline PEIS & $300.0 \mathrm{a}$ & $425.3 \mathrm{a}$ & $59.4 \mathrm{a}$ & $333.4 \mathrm{a}$ & 365.6 a $418.3 \mathrm{a}$ & $241.1 \mathrm{a}$ & $140.5 \mathrm{a} \quad 179.5 \mathrm{a}$ \\
\hline
\end{tabular}

${ }^{\mathrm{z}}$ Different letters within columns represent significant differences by LSD test ( 5 \% level).

Table 9 Effect of the management of nutrient solution on $\mathrm{Ca}, \mathrm{K}, \mathrm{Mg}$ and $\mathrm{NH}_{4}-\mathrm{N}$ concentration in juice of cucumber fruit $\left(\mathrm{mg} l^{1}\right)$.

\begin{tabular}{lrrrrrrrrrrrr}
\hline \hline \multirow{2}{*}{ Treatment } & \multicolumn{9}{c}{$\mathrm{Ca}$} & \multicolumn{1}{c}{$\mathrm{K}$} & \multicolumn{1}{c}{$\mathrm{Mg}$} & $\mathrm{NH}_{4}-\mathrm{N}$ \\
\cline { 2 - 11 } & Oct. 23 & Nov. 05 & Nov. 18 & Oct. 23 & Nov. 05 & Nov. 18 & Oct. 23 & Nov. 05 & Nov. 18 & Oct. 23 & Nov. 05 & Nov. 18 \\
\hline IIA normal & $612.4 \mathrm{a}^{\mathrm{z}}$ & $629.3 \mathrm{a}$ & $554.2 \mathrm{~b}$ & $191.0 \mathrm{a}$ & $38.5 \mathrm{a}$ & $166.0 \mathrm{a}$ & $385.2 \mathrm{~b}$ & $419.7 \mathrm{~b}$ & $439.2 \mathrm{~b}$ & $110.4 \mathrm{~b}$ & $353.8 \mathrm{a}$ & $286.2 \mathrm{a}$ \\
IIA 30:1 & $543.9 \mathrm{a}$ & $773.7 \mathrm{a}$ & $793.0 \mathrm{a}$ & $47.4 \mathrm{a}$ & $164.0 \mathrm{a}$ & $48.8 \mathrm{a}$ & $491.9 \mathrm{a}$ & $498.2 \mathrm{a}$ & $540.5 \mathrm{a}$ & $154.2 \mathrm{a}$ & $186.5 \mathrm{a}$ & $213.6 \mathrm{a}$ \\
IIA fuzzy & $735.3 \mathrm{a}$ & $839.7 \mathrm{a}$ & $630.5 \mathrm{~b}$ & $29.2 \mathrm{a}$ & $32.0 \mathrm{a}$ & $65.5 \mathrm{a}$ & $421.3 \mathrm{~b}$ & $500.2 \mathrm{a}$ & $471.1 \mathrm{~b}$ & $175.4 \mathrm{a}$ & $165.9 \mathrm{a}$ & $176.8 \mathrm{a}$ \\
PEIS & $621.2 \mathrm{a}$ & $678.5 \mathrm{a}$ & $513.5 \mathrm{~b}$ & $209.3 \mathrm{a}$ & $264.4 \mathrm{a}$ & $57.5 \mathrm{a}$ & $366.4 \mathrm{~b}$ & $432.5 \mathrm{~b}$ & $420.2 \mathrm{~b}$ & $163.8 \mathrm{a}$ & $144.8 \mathrm{a}$ & $197.6 \mathrm{a}$ \\
\hline
\end{tabular}

${ }^{\mathrm{z}}$ Different letters within columns represent significant differences by LSD test (5 \% level ).

めには適度の $\mathrm{NH}_{4}-\mathrm{N}$ を加用することが効果的であるという報 告 ${ }^{17)}$ もある. 今後, 生育中期にみられる $\mathrm{pH}$ 上昇の開始時期 の判断や培養液の $\mathrm{pH}$ 変動が生育に及ぼす影響, 供給する $\mathrm{N}$ 源の $\mathrm{NO}_{3}-\mathrm{N}: \mathrm{NH}_{4}-\mathrm{N}$ などを総合的に考慮した管理方法を 検討する必要がある.

収量については処理区間で有意な差はみられなかったが IIAS 30:1 区で最も多かった (Table 7). 果実搾汁液中無機 成分濃度については, 多くの成分で有意差はなかったが, $\mathrm{NH}_{4}-\mathrm{N}$ 供給量が少ないほど搾汁液中の $\mathrm{Ca}$ と $\mathrm{Mg}, \mathrm{PO}_{4}-\mathrm{P}$ の 濃度が高くなる傾向がみられ, Ca 濃度は IIAS 30:1 区で有 意に高かった (Table 8, 9). これは $\mathrm{NH}_{4}-\mathrm{N}$ を $\mathrm{N}$ 源とした場合 に葉中の $\mathrm{Ca}$ 含有率が低下したという報告 ${ }^{18)}$ と一致した. Ca は生体膜の構造と機能の維持に, $\mathrm{Mg}$ は葉緑素の生成に必 須であるため, これらの成分の含有量が高い IIAS 30:1区 で植物体の生育が最も良好であったと考えられる.

以上の結果から, 前報と同様に IIAS を用いることで PEIS よりも培養液の分析回数と肥料調製回数を低減し, 培養液 の濃度変動を抑制できることが示された. また $\mathrm{NH}_{4}-\mathrm{N}$ 供給方 法は, $\mathrm{NH}_{4}-\mathrm{N}$ の養分吸収量を正確に予測できないため技術 的に濃度維持が困難であり, さらに培養液の $\mathrm{NH}_{4} \mathrm{-}$ 濃度の 維持を試みる管理では $\mathrm{NH}_{4} \mathrm{-N}$ が過剩に供給され培養液の
$\mathrm{pH}$ が極度に低下することから, 供給される $\mathrm{NO}_{3}-\mathrm{N}$ 量との比 率に基づき $\mathrm{NH}_{4}-\mathrm{N}$ を供給する方法が実用的と考えられた.さ らに, $\mathrm{N}$ 源に対する生育反応は作物種によって異なり ${ }^{19)}$, 土 耕と水耕の培地における硝化能の違い, 光 ${ }^{20)}$ や温度 ${ }^{21)}$ 条 件などによっても異なるため, 今後窒素同化のモデリングや $\mathrm{NO}_{3}-\mathrm{N} / \mathrm{NH}_{4}-\mathrm{N}$ 比制御による $\mathrm{pH}$ 制御技術の確立を図ってい く必要がある.

\section{引用文献}

1）霧村雅昭, 位田晴久. イオン濃度制御法と EC 制御法 を融合させた新しい培養液管理法の開発. 植物環境工 学. 18(4): 261-270. 2006.

2) 位田藤久太郎. 水耕栽培法に関する諸問題 [5]-水耕 液のpH 管理一.農業および園芸.57: 327-331. 1982.

3) Harper, J. E., Nicholas, J. C. Control of nutrient solution $\mathrm{pH}$ with an ion exchange system: Effect on soybean nodulation. Physiol. Plant. 38: 24-28. 1976.

4) 森次益三, 河崎利夫. 自動 $\mathrm{pH}$ 調整水耕栽培装置の製 作. 日本土袞肥料学雑誌. 48(7, 8): 243-247. 1977.

5) 永井輝行, 鹿子嶋力, 位田藤久太郎. 養液栽培におけ る根の環境の制御に関する研究-第 2 報一水耕培地の 自動制御装置の試作. 福井短大紀要. 3: 23-47. 1978. 
6) Savvas D, Gizas G. Response of hydroponically grown gerbera to nutrient solution recycling and different nutrient cation ratios. Scientia Horticulturae. 96: 267-280. 2002

7）飯塚隆治. 水耕培養液中のアンモニア態窒素の硝酸 化. 日本土壌肥料学雑誌. 49 (4): 296-303. 1978.

8) Ikeda H, Osawa T. Nitrate- and ammonium- N absorption by vegetables from nutrient solution containing ammonium nitrate and the resultant change of solution pH, J. Japan. Soc. Hort. Sci. 50 (2): 225-230. 1981.

9) Savvas D, Manos G. Automated composition control of nutrient solution in closed soilless culture system. J. Agric. Engng Res.73: 29-33. 1999.

10）塚越 覚. $\mathrm{pH}$. 社団法人日本施設園芸協会編, 養液 栽培の新マニュアル，誠文堂新光社，東京. 180-183. 2002.

11）佐和隆光. 回帰分析. 朝倉書店, 東京. 150-153. 1979.

12）赤池弘次. 統計モデル選択 AIC と MDLと BIC. オペ レーションズ・リサーチ. 41(7): 375-378. 1996.

13) 苅田正雄, 上田太一郎. Excel でできる最適化の実践ら くら読本. 同友館, 東京. 140-170. 2003.

14）霧村雅昭, 位田晴久. イオン濃度制御キュウリ養液栽培
において $\mathrm{NH}_{4}-\mathrm{N}$ 濃度設定值が培養液の $\mathrm{pH}$ 変動に及 ぼす影響. 植物環境工学. 17(4): 199-204. 2005.

15）位田晴久, 霧村雅昭, 久保田豊, 中原光久. 複合肥料 を用いたイオン濃度制御によるキュウリの養液栽培. In: 農業環境工学関連 4 学会 2001 年合同大会講演要旨, つくば. 6 月 27 日-29日. 237. 2001.

16）熊沢喜久雄. 植物栄養学大要. 養賢堂, 東京. 102-103. 1974.

17）池田英男. 用水と培養液の調整. 社団法人日本施設園 芸協会編, 養液栽培の新マニュアル. 誠文堂新光社, 東京. 140-166. 1996.

18）池田英男, 大沢孝也. 施用窒素形態とそ菜の適応性 (第 1 報 ). 園芸学会雑誌. 47 (4): 454-462. 1979.

19）但野利秋, 田中 明. アンモニア態および硝酸態窒素 適応性の作物種間差(第 1 報). 日本土䁃肥料学雑誌. 47(7): 321-328. 1976.

20) 鄭 顕福, 丸尾 達, 篠原 温, 伊東 正. トウガラ シの NFT 栽培における遮光と培養液中の窒素形態が 生育, 収量に抢よぼす影響。園芸学会雑誌. 61(別2): 304-305. 1992.

21) Frota J E, Tucker T C. Temperature influence on ammonium and nitrate absorption by lettuce. Soil Sci. Am. Proc. 36: 97-100. 1972. 